\title{
Spiritual Quotient of Tingkeban Tradition in Javanese Culture
}

\author{
Nurpeni Priyatiningsih \\ Veteran Bangun Nusantara University \\ Sukoharjo, Indonesia \\ nurpenipriyatiningsih@gmail.com
}

\begin{abstract}
Tingkeban is a traditional custom of Javanese people conducted in seven month gestation. Through this tingkeban traditional custom, people have expectation and belief in the security of baby that will be born. Tingkeban traditional procession includes: determining the day, determining the time, providing equipment, selamatan (ceremonial meal), siraman (bathing ceremony), brojolan, cengkir gading breaking, rujakan. Spiritual quotient in tingkeban ceremonial procession contains an expectation for the security of prospect mother and baby. In addition, to Javanese people, it is the manifestation of gratitude to God the Almighty. Furthermore, the tingkeban tradition functions as a means of expressing gratitude to God Almighty, a means of sharing with all people, and a means of reinforcing mutual cooperation (gotong royong) within society. Tingkeban tradition is a Javanese people's custom having positive value. Tingkeban also gives education to the society that this tradition is the manifestation of gratitude and pray for the security of prospect mother and baby.
\end{abstract}

Keywords - tingkeban; tradition; spiritual quotient

\section{INTRODUCTION}

\section{A. Background}

In daily life, Javanese people are inseparable from traditions they inherit. These traditions are generally followed by Javanese people with certain ceremonies according to purpose.

Javanese people have much cultural information to be studied along with time development. It is noteworthy that an attempt of revealing Javanese people's thought, perspective and life will never be completed and even still needs new ways to reveal the mystery of Javanese culture. Tingkeban or the celebration of 7-month gestation and other similar rites, according to social and cultural science, is a form of initiation, a means used to pass through an anxiety. In this case, it is the prospect parents' anxiety with their granted expectation during pregnancy, childbirth, and the baby to be born. Therefore, a rite replete with meaning had been created since the period of ancestors when religion had not been recognized and it is still believed by some of people until today.

Balong Hamlet people have spiritual quotient helping them developing themselves comprehensively through creation likely to apply positive values in a rite or traditional ceremony such as tingkeban. In tingkeban, there are some stages of implementation replete with meaning; from those stages, we can find out that Beran Village people uphold Javanese customary traditional values and have Spiritual Quotient.

\section{B. Problem Statement}

Considering the background suggested above, the problem statement can be formulated as follows:

1. What is the procedure or procession of tingkeban in Javanese culture?

2. What are Spiritual Quotient values contained in tingkeban in Javanese culture?

3. What is the function of tingkeban rite in Javanese culture?

\section{DISCUSSION}

\section{A. Procession of Tingkeban in Javanese Culture}

Every ceremony has its own procedure in holding the rite. Meanwhile, the procedure or procession of tingkeban for Javanese people is as follows:

\section{1) Time}

This rite is held before 7-month gestation, and the prospect parents of baby should determine the good day according to Javanese count. According to Javanese count, the good days are those with even neptu (neptu genap) and the number is 12 or 16 .

The best implementation time is at 09.00-11.00; at that time, prospect mother should take a bath and wash her hair cleanly. It reflects a pure and clean will. Meanwhile, tingkeban rite should begin at about 15.00-16.00. It is believed that at that time, the fairies begin to take a bath.

\section{2) Selamatan or Kendhuri}

Tingkeban rite starts with kendhuri event attended by neighbors, relatives, friends, and etc. All of kenduri instruments are brought before the attendees. After all of kenduri instruments have been served, the village elder or Modin will ngujubne or explains the purpose or the objective of the rite organization.

\section{3) Siraman}

This siraman (ceremony of bathing) is conducted to the prospect parents of baby including father and mother with water coming from 7 water sources and done by seven family elders and led by local dukun bayi (women helping child delivery) or village elders.

4) Pantes-pantes or changing dress 7 times

In this pantes-pantes event, the prospect mother wears 7 types of cloth or kain and kebaya. The first to the six kain and kebaya are the ones showing off luxury and glory. The 
attendees will be asked whether or not the prospect mother wear those dresses properly, and they will reply: "dhereng Pantes" (not yet). After the prospect mother wears the seventh cloth, kain truntum with simple motif, they just reply: "pantes" (it has been proper).

\section{5) Brojolan or Glundhungan Cengkir Gadhing}

In this brojolan event, prospect grandma from prospect mother carries on gading coconut accompanied by her ibu besan (her daughter in law's mother). Previously gading coconut is penetrated into the cloth worn by the prospect mother through her womb and then going down, while praying "lahir putra juga mau, lahir putr juga mau asal ibu dan bayinya selamat lepas dari marabahaya dan yang pokok lancar (either baby boy baby girl who is born will be welcomed happily as long as mother and her baby are safe and independent of peril, and everything runs smoothly).

\section{6) Cengkir Gadhing breaking}

Prospect father breaks the coconut by choosing one out of two gading coconuts painted with Kamajaya and Kamaratih figures. The objective of painting is to make the baby to be born has physique and characteristics like those puppet characters.

“"'Yen lanang kaya Kamajaya, yen wadon kaya Dewi Ratih" meaning that when it is a baby boy it will be like Kamajaya and when it is a baby girl, it will be like Dewi Ratih.

\section{7) Rujakan}

Rujakan consists of various fruits such as cucumber, orange, watermelon, apple, star fruit, rose apple, and bengkoang. All of those are served as well as possible in order to feel delicious and tasty. It is intended to make the baby to be born pleasurable to family.

\section{B. Spiritual Quotient values in Tingkeban event in Javanese Culture}

1) Spiritual Quotient values in Uborampe Tingkeban or Equipment or instrument of Tingkeban

a) Two Cengkir/gading coconuts and tray to put them on. The two Cengkir gading are painted with Kamajaya and Kamaratih figures. Cengkir means ngencengake pikir or determining to welcome the presence of baby entrusted by God (Illahi). The determination intended is to take care of and to educate the baby to be a child with noble character.

b) A variety of dresses: underwear, seven sheets of batik cloth with different motif including: Sido Mukti meaning prestigious, that is, being happy and respected due to prestige; Sido Luhur meaning decorum and noble character; Truntum meaning parent's noble character sent down (truntum) to child; Parang Kusuma meaning having intelligence like the sharp blade and having agility; Semen Rama meaning that the child should have affection to his/her fellow just like Rama and Sinta's affection to their people; Udan Riris meaning that the child can create a refreshing situation and is eye-catching to everyone seeing him/her; Chicken claw, meaning that child should earn living smartly thereby can meet his/her life needs, and fortunately can be rich and prosperous.

c) Tumpeng Kuat. The meaning of tumpeng kuat is to make the baby to be born healthy and strong, and to give the parents physical and spiritual power.

d) Ayam Bekakah (Iwak Ingkung). Ayam bekakah has a symbol of expectation in order to always be sincere and to have the feeling of togetherness in any condition.

e) Bubur Sengkolo. The expectation of bubur sengkolo is that hopefully the one (both baby and his/her family) holding the event will be "kali sing sambi kala" or independent of any peril.

f) Ketupat (rice cake boiled in a rhombus-shaped packet of plaited young coconut leaves). It means always introspecting ourselves, and always forgiving others.

g) Jajanan pasar. It means that the baby will get much and abundant livelihood later.

h) Keleman. It means that the baby will get much livelihood and can live modestly.

i) Rujakan. It means it is improper to invite the old pregnant woman in ajimak saresmi (to have sexual intercourse) for taking care of the infant in the womb.

j) Pisang Ayu or Pisang Raja (Ayu Banana or Raja Banana). It smells good and is sweet, containing the expectation for happiness.

k) Nasi Tumpeng. Nasi tumpeng (cone-shaped rice) is the symbol of application for safety. To Javanese people, mountain symbolizes sturdiness, strength, and safety.

1) Nasi Golong. It is a prayer to ask for abundant livelihood (golong-golong).

m) Bunga Setaman. It is intended to result in fragrant aroma. The flowers used are rose, jasmine, and kenanga. Each of flowers has its own meaning. Jasmine symbolizes purity; it means that doing any activity should be based on pure intention. Rose symbolizes bravery; undertake this life needs bravery to change this world with kindness. Kenanga flower means "remember please". It means that human being is inseparable from the culture of imitating or doing what others do before. What is imitated is of course life kindness in this world.

n) Bubur Procot. It is called procot with the expectation that the baby will be born easily or procat-procot.

o) Takir Plonthang or Nasi Punar (consisting of seven Takir). It is intended to make the baby born safely and healthily without any obstacle.

p) Seven water sources. Water used during siraman is taken from seven different water sources. It contains the expectation for pitulungan (help).

2) Spiritual Quotient values in the implementation or procession of Tingkeban in Javanese Culture

a) Selamatan or Kendhuri rite. Kendhuri or so called bancakan. Before tingkeban rite begins, selamatan or bancakan rite is conducted first in the bathing place; it is intended to pray for the safety and the smoothness of tingkeban implementation.

b) Siraman. Siraman or bathing is the rite symbolizing the self cleanliness, either physically or mentally. This siraman aims to free the prospect mother from sins so 
that she will deliver the baby without moral burden and his baby delivery will run smoothly. And after she has been clean, she should pray to God the Almighty in order to be blessed so that the baby will be born safely.

c) Pantes-pantes or changing dress 7 times. After siraman, the prospect mother changes her dress seven times and wears white cloth. The white cloth is worn as the first dress base before pantes-pantes event. The white cloth represents that the baby to be born is pure, and blessed. Thereafter, in pantes-pantes event, the prospect mother wears 7 types of cloths seven times. Seven-motif clothes represent good characteristic or personality. During wearing the seven clothes, she will ask whether or not the cloth is proper to be worn. It means that the prospect mother should think of not only secularity but she should appear modestly.

d) Brojolan. In this brojolan event, there are two cengkir gadhing (young gading coconuts) that have been painted with Kamajaya and Dewi Ratih figures. This even symbolizes the expectation that the baby to be born will have physique and characteristic like the puppet figures. And brojolan itself means the expectation that the baby will be born easily.

e) Cengkir gadhing breaking. It is believed that through cengkir breaking, the ideal will be achieved easily.

f) Rujakan. Rujakan is intended to make the baby born pleasurable and preferable to family and many people. It is believed that when the rujak sold is not delicious, a baby boy will be born, but when the rujak is delicious, a baby girl will be born.

\section{Function of Tingkeban Rite in Javanese Culture}

Every ceremony or rite has its own function, used by a group of people for certain purpose. The function of tingkeban rite in Javanese culture is as follows:

\section{1) As a means of removing misfortune}

Essentially, this tingkeban rite is the one believed as a means of removing misfortune.

\section{2) As a means of expressing gratitude to God the Almighty}

After tingkeban rite has been completed, bancaan rite is then conducted. Bancaan is the expression of gratitude to God the Almighty for His Bless and the fetus given to pregnant woman.

\section{3) As a means of preserving culture}

The presence of tingkeban can be a means of preserving (menguri-uri) our culture, Javanese culture, which has been sent down by our ancestor from one generation to the next.

4) As a means of strengthening mutual cooperation (gotong royong) and commonness
Javanese people always inculcate the spirit of mutual cooperation in life, meaning that any problem becoming collective interest should be prioritized and completed together. Mutual cooperation values are contained in tingkeban rite; it can b seen from the people who are willing to help the event organization from preparation to the completion. They pray collectively for the safety and the health of prospect mother and baby to be born.

5) As a means of applying for help or praying to God the Almighty

It can be seen from various symbolic meaning contained in the equipment and the procession or procedure of tingkeban.

6) As a means of appreciating each other within the members of society

Appreciating or being tolerant to each other is a socialcultural value contained in Javanese community. This character is very important in life, as it can mitigate the conflict occurring.

\section{CONCLUSION}

The conclusion that can be drawn in this article is as follows:

Tingkeban traditional procession in Javanese culture starts with kenduri, siraman, pantes-pantesan/changing dress 7 (seven) times, brojolan, cengkir (young coconut) breaking and ends with rujakan. Spiritual Quotient (SQ) value contained in Tingkeban tradition includes the request to God the Almighty for safety and happiness for the couple, the process of self purification in the attempt of praying to God Almighty, praying for the safety of fetus existing in the womb and mother until the delivery process.

Meanwhile, tingkeban tradition in Javanese community functions as, among others: 1) a means of removing misfortune, 2) as a means of expressing gratitude to God the Almighty, 3) as a means of preserving Javanese culture, 4) as a means of strengthening mutual cooperation, 5) a means of asking for help or praying to God the Almighty, and 6) as a means of appreciating each others.

\section{References}

Bratawidjaja. (1985). Tradisi adat Jawa. Jakarta: Gramedia. Danajaya. (1997). Foklor di Indonesia. Jakarta: Gramedia. Herusatoto, Budiono. (2008). Simbolisme Jawa. Yogyakarta: Ombak.

Moleong. (2006). Metode penelitian kualitatif. Bandung: PT Remaja Rosdakarya.

Soemarjan. (1980). Kesenian Jawa. Jakarta: Gramedia.

Sutopo, H.B. (2008). Manusia dan kebudayaan. Jakarta: Dain Rakyat. 